\title{
DETERMINATION OF SHARE PRICE OF AGRO ALLIED FIRMS: EVIDENCE FROM NIGERIA
}

\author{
Adedoyin Isola LAWAL ${ }^{1}$, Ezeikel OSENI ${ }^{2}$, Abiola J. ASALEYE ${ }^{3}$, Bukola LAWAL-ADEDOYIN ${ }^{* *}$, Crystal 0. \\ ELLEKE $^{5}$ \\ ${ }^{1}$ Senior Faculty, Department of Accounting and Finance, Landmark University, Omu Aran, Nigeria; ${ }^{3,4 *}, 5$ Faculty,
} Department of Accounting and Finance, Landmark University, Omu Aran, Nigeria; ${ }^{2}$ Adjuct Professor, Dept. of Banking and Finance, University of Lagos, Nigeria.

Email: *lawal.bukola@lmu.edu.ng

Article History: Received on $26^{\text {th }}$ March 2020, Revised on $10^{\text {th }}$ June 2020, Published on $19^{\text {th }}$ August 2020

Abstracts

Purpose: The study aims to investigate the determinant of the share price of agro-related firms listed on the Nigerian stock exchange.

Methodology: We employed regression analysis, unit root test as well as vector correction model to determine the degree of relationship between share prices and each of return on assets (ROA), earnings per share (EPS), dividend per share (DPS).

Findings: The study found that share price is majorly influenced by earnings per shares, while other variables lag it.

Practical implications: Results from the study have some possible policy implications, for instance, it is recommended that policymakers should put in place conducive market environments that will stimulate earnings from investments. Investors should on the other hand pay keen attention to information within and outside the economy when making investment decisions.

Originality/Value: This study is one of the first studies on determinants of share prices with a focus on agro-allied firms.

Keywords: Stock Market, Agro-allied Firms, Share Prices Determination, Dividend Per Share, Return on Assets, Nigeria.

\section{INTRODUCTION}

The capital market provides a platform for the sale and purchase of securities over the medium and long term (Ayoopo et al, 2015; Adelegan 2003; Fashina et al, 2018; Isola et al, 2018). Nigeria's stock market was set up to give organizations and other market practitioners a platform for raising long-term advances at negligible expenses to catalyse the nation's assets among contentious customers.

The Nigerian stock exchange, referred to prominently as the NSE, was established in 1960 as the Lagos Stock Exchange. It changed its name to Nigerian Stock Exchange in December 1977, and currently has various branches with Lagos as its headquarters (Lawal et al, 2016; Lawal et al, 2018). Nigeria Stock Exchange gives investors the opportunities to raise funds to finance their business interests using the market mechanism. Several businesses trade on the floor of the exchange with majority trading in non-agro related activities. This raises a concern giving the fact that Nigeria is largely an agrarian economy with over $70 \%$ of her population relying on agriculture as a means of livelihood (Asaleye et al, 2018a; Lawal et al, 2017). As noted by Lawal et al, 2018, very few players on the floor of the Nigerian Stock Exchange trades in agro-allied businesses Asaleye et al, 2018b; Babajide et al, 2020; Lawal et al, (2020a). According to Lawal et al, (2019a), agro-allies firms operate in a way different from conventional firms, thus the return on investment differs in terms of seasons and volumes.

This triggers government vigorous investment in the sector with the intention of boasting this sub-sector. Despite huge government investment in the sector, the private sector response has not been encouraging. This could be due to several factors ranging from poor return on investment, low dividend payment among others. The question is what are the factors that determine the share prices of these agro-alloyed firms in Nigeria?

The core of the current study is to determine the key factors influencing the prices of listed companies on the stock exchange floor of Nigerian stock exchange, with a focus on agro-allied companies. Our key goals are set out as follows:

1. To investigate whether there is a significant relationship between the return on assets (ROA) and the share price of agrorelated companies.

2. To assess whether the dividend per share (DPS) has a significant relationship with the share price of agro-allied farms on the floor of the Nigeria Stock Exchange.

3. To examine the nature of the relationship between earning per share and share price of agro-allied companies. 


\section{LITERATURE REVIEW}

\section{Theoretical Framework}

The theories governing the current study are: Stakeholder Theory which states that both agro-allies and stock exchange participants are key players in achieving the organization's growth and development, thus operating with stakeholders and not just shareholder mindset Ndede \&Jagongo, (2014); Fontaine et al, (2006); Lawal et al, (2020b); Ehikioya, (2015); Beck and Levine, (2004); Chelimo and Kiprop, (2017), Lawal et al, (2018). Other theories are the Efficient market hypothesis theory which states that the actual price of a security will be a good estimate of its intrinsic value, and that the prices of assets fully reflect every publicly available information. (Fama, 1970) classified efficient markets into three: weak-form, semi-strong form and strong form efficient. The Capital Assets Pricing Model, which emphasizes the impact of the capital market on the aggregate economy. The hypotheses are that, by channelling money into the agricultural sector, the capital market induces development Lawal et al, 2017b.

\section{EMPIRICAL LITERATURE}

This section provides a review of some of the existing literature on the subject matter.

Saragih (2018) examined the impact of returns on assets, return on equity, and debt to equity on stock return in wholesale and retail trade companies listed on the Indonesia stock exchange. The study employed multiple linear regression and noted that return on assets has a negative effect on stock returns, while both the return on equity and debt to equity ratio have a positive impact on stock return for the studied economy. These findings was supported by the study of Ilmiyono (2019) and Idawati and Wahyudi (2015) who both noted that the impact of return on the asset on stock market prices is not always positive but timevarying.

Mogonta and Pandowo (2016) employed multiple regression to analyze dataset on return on asset (RoA), return on equity (RoE), and earnings per share (EPS) for seven (7) mining firms listed on the Indonesian stock market based on data sourced from 2011 to 2015. The study noted that the three variables have a varying degree of influence on stock market prices. This position was supported by the findings of Utami and Darmawan (2019) who employed a purposive sampling method to analyse data sourced from 53 companies on the Indonesia stock exchange from the period 2012 to 2016.

Pandey (2019) examined the effect of both macroeconomic variables proxy by interest rate, exchange rate, tax rate, inflation rate; and microeconomic variables like the return on asset (RoA), return on equity (RoE) and earnings per share (EPS) on share price determinants in India pharmaceutical firms listed on the Indian stock exchange and some selected developed economies comprises of the USA, UK, Germany, France, and Switzerland. The study noted that pharmaceutical firms share prices of the studied economies are largely influenced by macroeconomic variables with microeconomic variables like return on asset, return on equity having little or no impact on stock price movement.

Sharif, Purohit, and Pillai (2015) examined the determinants of stock prices movement for Bahrain based on data sourced from the year 2006 to 2010. The study employed pooled OLS regression with robust standard errors, fixed effects and random effect techniques and observed that return on equity, book value per share, dividend per share, dividend yield, price-earnings and firm size are significant determinants of share price in the Bahrain stock market while debt to assets and earnings per share have no impact on stock prices.

For the Pakistaini economy, Hunira et al, (2014) examined the determinants of stock prices of four non-financial sectors - sugar, chemical, food and personal care, and energy - using the OLS to analyse data sourced from 2006 to 2011 . The study noted that dividend is the prime determinant of share prices. This result was in line with the study of Zainudin, Mahdzan, and Yet (2017) for the Malaysian stock market, who noted that dividend policy is the major determinants of share price movement.

For the Turkish economy, Kassouri and Altintas (2020) examined the impact of exchange rate volatility on stock market price determination. The study employed complex asymmetric models and a non-linear framework to analyze monthly data sourced from January 2003 to December 2018. The study noted that the impact of the exchange rate on stock market pricing is better revealed from a non-linear asymmetric model.

Aatola, Ollikainen, and Toppinen (2013) examined the price determination of the European Union Emission Allowance (EUA) of the European Union Emission Trading Scheme (EU ETS). The study postulated an uncertain permit price and risk-averse firms that can hedge in a forward market system. The study employed several econometrics models and a battery of unit root techniques to analyze a daily dataset sourced from 2015 to 2010 in the EU ETS markets. The study noted that evidence abound to state that a significant relationship exists among the German electricity prices, coal prices, stock market prices and the market fundamentals and the EUA prices. The study also noted that the EUA forward price depends largely on the fundamentals. 
In a related development, Hintermann, Peterson, and Rickels (2016) examined the links between price and market behavior of EU ETS focusing on the second phase period. The study noted that allowance prices are relatively lower for the studied economies (see also Zhang and Sun, 2016).

Ariff, Chung, and Shamsher (2012) examined the impact of interest rate, money supply, and liquidity effect on share price determination. The study employed a battery of simultaneous equations to analyze quarterly data sourced from 1960 to 2011 and noted that liquidity effect and money supply impact positively in determining asset prices for the studied economy. The study noted that the money supply is endogenously influenced, following a post-Keynesian economic model.

For China, Geertsema and Lu, (2019) employed simultaneous equations to examine the existence of bi-directional causality between Initial Public Offer (IPO) initial returns and oversubscriptions ratios in order to determine factors that induce price formation. The study scope ranges from 1996 to 2015. The study noted that a unidirectional relationship exists from oversubscription ratios to IPO initial returns, and that price is largely determined by market forces in China.

For electrolytic related prices, Shi, Wang, Feng, and Wu, (2018) employed a structural demand-supply model to examine what influences price determination. The study noted that the prices of electricity-related stock are largely influenced by the transmission effect of the equilibrium price of the electrolytic mechanism.

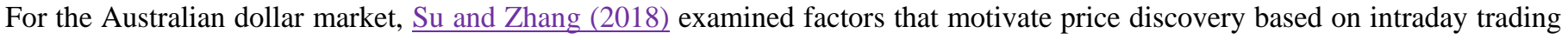
data sourced from January 1999 to December 2013. The study employed a battery of econometric models and observed that macroeconomic news, order flows, and market state variables such as returns, volatility, trade volume and bid/ask spread are key determinants of price discovery in the studied economy.

\section{METHODOLOGY}

The data for this study were sourced from the publication of the Central Bank of Nigeria (various issues) and the Nigerian Stock Exchange (various issues). It comprises annual data sourced from 2006 to 2018. The period is strategic as its starting date precedes the 2007/2008 global financial crisis and the end date is after the recovery from the economic recession of 2016Q3 to 2017Q2 witnessed in Nigeria. We used regression analysis, unit root test as well as vector correction model to analyse our results. We first estimated their individual stationary levels by using the Augmented Dickey-Fuller test which helps to test the time series data for unit root existence. We then employed a simple regression model and variance decomposition estimates to examine the relationship among the variables.

The specification for the regression model is as follows.

$\mathbf{Y}=\beta \mathbf{0}+\beta 1 \times 1+\beta 2 \times 2+\beta 3 \times 3+\beta 4 \times 4+\mu$

Where $\mathrm{y}$ is an independent variable while $\mathrm{x} 1-4$ are the independent variables, $\mathrm{Y}=$ the share price of listed agro-allied firms represent by return on asset (ROA), $\beta=$ constant term, $\mathrm{X} 1=$ share price of agro-allied firms (SHP), $\mathrm{X} 2=$ return on asset (ROA), X3=dividend per share (DPS), X4=earnings per shares (EPS), $\mu=$ the error terms.

\section{RESULTS/FINDINGS}

\section{Unit Root Test}

The Augmented Dickey-Fuller test was performed for the variables used to check for both stationary and non-stationary results.

Table 1: Unit Root Test

\begin{tabular}{lllll}
\hline & T-stat & Probability & Significance level & Integration order \\
\hline SHP & -3.178569 & 0.0017 & At level & $\mathrm{I}(0)$ \\
\hline ROA & -4.013928 & 0.0001 & At level & $\mathrm{I}(0)$ \\
\hline DPS & -3.797985 & 0.0002 & At level & $\mathrm{I}(0)$ \\
\hline EPS & -2.879881 & 0.0042 & At level & $\mathrm{I}(0)$ \\
\hline
\end{tabular}

Source: Author's computation with EViews 10

Table 1 above provides a description of the results of unit root tests obtained for the various variables at the point. The Augmented Dickey Fuller test was conducted on all variables and the results showed that the variables were stationary at the level of $1 \%, 5 \%$ and $10 \%$ of the critical value because their T statistics at the levels were higher than the critical value of $1 \%$, $5 \%$ and $10 \%$. 


\section{Linear Regression Analysis (Ordinary Least Square)}

Table 2 summarizes the findings of the linear regression analysis performed to determine if a significant relationship exists between the independent variables and the dependent variable. The condition for the OLS regression is that each variable's likelihood value should be less than 0.05 at a significance level of 5 percent, for each variable, the T-Statistics value should be greater than 2 for each variable. DPS meets the three criteria and thus shows that the relationship between DPS and SHP is significant. On the other hand, ROA and EPS do not meet the criteria, and hence the null hypothesis is accepted for their case.

Table 2: Linear Regression Analysis (Ordinary Least Square)

\begin{tabular}{lllll}
\hline Variables & Coefficient & Standard error & T-stat & Probability \\
\hline SHP & 1.564309 & 1.564007 & 1.96003 & 0.07455 \\
\hline ROA & 1.486968 & 1.800215 & 0.825995 & 0.08104 \\
\hline DPS & 29.07226 & 1.511979 & 19.22795 & 0.0000 \\
\hline EPS & 0.001286 & 0.102020 & 0.012601 & 0.0900 \\
\hline C & -0.866729 & 10.15467 & -0.853472 & 0.0650 \\
\hline
\end{tabular}

Source: Author's computation 2020

\section{Variance Decomposition}

Thanks to their own shocks and the shocks of the exogenous variables ROA, DPS and EPS, the variance decomposition would be used to evaluate the magnitude of the changes within the dependent variable SHP.

Table 3: Variance Decomposition of ROA

\begin{tabular}{llllll}
\hline Variance Decomposition of ROA & & & & \\
\hline Period & S.E. & SHP & ROA & DPS & EPS \\
\hline 1 & 2.872936 & 0.001106 & 99.99889 & 0.000000 & 0.000000 \\
\hline 2 & 3.605150 & 0.009369 & 99.74248 & 0.248080 & $7.06 \mathrm{E}-05$ \\
\hline 3 & 4.042979 & 0.012711 & 99.44690 & 0.419751 & 0.120640 \\
\hline 4 & 4.315271 & 0.011478 & 99.16848 & 0.461693 & 0.358350 \\
\hline 5 & 4.493649 & 0.013820 & 98.89496 & 0.480487 & 0.610735 \\
\hline
\end{tabular}

Source: Author's computation with Eviews 10

Table 3 above shows the decomposition of ROA variances. It can be deduced from the table that the variability in ROA's forecast error shock is explained by about 99.9 percent variance in the first half. The variance in ROA's forecast error shock is explained by around 0.24 percent of the variability in the variable DPS in the second period. The variation in ROA's forecast error shock is explained by about 0.12 percent of the variation in EPS in the third period. The variation in the ROA's forecast error shock is explained by about 0.013 percent of the variation in SHP in the fourth period.

Table 4: Variance Decomposition of DPS

\begin{tabular}{llllll}
\hline \multicolumn{2}{l}{ Variance Decomposition of DPS } \\
\\
\hline Period & S.E. & SHP & ROA & DPS & EPS \\
\hline 1 & 3.183229 & 29.90621 & 0.043260 & 70.05053 & 0.000000 \\
\hline 2 & 4.178576 & 56.65610 & 0.118840 & 43.15398 & 0.071078 \\
\hline 3 & 4.694356 & 64.14157 & 0.095862 & 35.70279 & 0.059777 \\
\hline 4 & 5.101583 & 62.88990 & 0.089497 & 36.96146 & 0.059140 \\
\hline 5 & 5.379319 & 62.59849 & 0.096850 & 37.23865 & 0.066008 \\
\hline
\end{tabular}

Source: Author's computation with EViews 10

Table 4 above shows the decomposition of DPS variance. It can be deduced from the table that the variability in DPS ' forecast error shock is clarified in itself by about 70.05 percent variance in the first period. The variability in the DPS forecast error shock is explained by around 0.12 percent of the variance in the ROA variable in the second period. The variance in DPS ' forecast error shock is explained by around 0.06 percent of the variability in EPS in the third period. The variance in the DPS ' forecast error shock is explained by about 62.6 percent of the variability in SHP in the fourth period. 
Table 5: Variance Decomposition of EPS

\begin{tabular}{llllll}
\hline \multicolumn{2}{l}{ Variance Decomposition of EPS } & & & \\
\\
\hline Periods & S. E. & SHP & ROA & DPS & EPS \\
\hline 1 & 64.12466 & 0.003791 & 1.400333 & 0.484984 & 98.11089 \\
\hline 2 & 79.81568 & 0.059526 & 1.301045 & 0.862552 & 97.77688 \\
\hline 3 & 84.00364 & 0.057838 & 1.176663 & 1.118354 & 97.64714 \\
\hline 4 & 84.97183 & 0.074419 & 1.201364 & 1.142369 & 97.58185 \\
\hline 5 & 85.22952 & 0.104712 & 1.295091 & 1.150287 & 97.44991 \\
\hline
\end{tabular}

Source: Author's computation with EViews 10

Table 5 above shows the decomposition of the EPS variance. It can be deduced from the table that the variability in EPS ' forecast error shock is explained in itself by about 98.1 percent variance in the first half. The variability in the projected error shock of EPS is clarified in the second period by about 1.30 percent of the variance in the variable ROA. The variation in EPS ' forecast error shock is explained by about 1.11 percent of the variation in DPS in the third period. The variation in the EPS ' forecast error shock is explained by around 0.10 percent of the variation in SHP in the fourth period.

It can be noticed from the diagram above that all the blue dots are inside the circle. That means the model is stable. Model stability means which economic predictions can be made on a model basis.

Overall, the results show that the share price of agro-allied firms in Nigeria is largely influenced by earnings per share. This is in line with existing studies like Mogonta and Pandowo (2016) for the mining firms listed on the Indonesia stock exchange. The results also correspond with the findings of Hunira et al, (2014) for Pakistan.

However, the result contradicts the findings of Saragih et al, (2018) who documented a negative relationship between share prices and return on assets. The results were also at variance with the findings of Pandey (2019), who noted that macroeconomic fundamentals like inflation rate, exchange rate, interest rate, tax rate are the key determinants of share prices in India and the Western economies. Our results also differ from the findings of Sharif et al, (2015), who noted that earnings per share have no impact on share price determinations for the Bahrain economy. Unlike the findings of Saragih (2018), who documented the existence of a negative relationship between RoA and share prices, our results observed the existence of the positive but insignificant relationship between RoA and share prices, our results was similar to the findings of $\underline{\text { Ilmiyono }}$ (2019) and Idawati and Wahyudi (2015) who both noted that the impact of return on the asset on stock market prices timevarying. The differences between our results and some of the existing studies could be as a result of the size and scope of the variables employed, the nature of the industry studied, among others. For instance, Saragih (2018), employed fewer dataset, Mogonta and Pandowo (2016) focused on mining sub-sector with have almost the same characteristics like the agro-allied firms in our case.

\section{CONCLUSION}

This research work analysed the share price of agro-allied and Non agro allied companies listed on the stock exchange market in Nigeria. This study is based on annual variable results, a total of 12 years, starting from 2006 to 2018. This research work analysed the share price of agro allied and Non agro allied companies listed on the stock exchange market in Nigeria. In the analysis, the ordinary least square regression approach was used for the data collected prior to the stationary test and after the stationary test, unit root test was also performed to know at what level the variable is stationary, descriptive statistics were collected to evaluate the mean and standard deviation, correlation testing was also conducted to evaluate the relation between dependent and independent variables. The hypotheses were tested to determine the level or percentage of the dependent-independent variable relation. In this study, all of the independent variables affect the financial profitability of agro allied and Non agro allied companies.

\section{ACKNOWLEDGEMENT}

The author wishes to acknowledge the Management of Landmark University, Omu Aran, Nigeria for providing financial grants to undertake the study.

\section{AUTHORS CONTRIBUTION}

Author One did the conceptualization and the first and final drafts, Authors Two and Three did the Methodology and Results while Authors Four did the literature review. 


\section{REFERENCES}

1. Aatola, P., Ollikainen, M. And Toppinen, A. (2013). Price determination in the EU ETS market: Theory and Econometric analysis with market fundamentals. Energy Economics 36, 380 - 395. https://doi.org/10.1016/j.eneco.2012.09.009

2. Adelegan, O. J. (2003). Capital Market Efficiency and the Effects of Dividend Announcements on Share Prices in, African Development Review 15(2-3) 218-236. https://doi.org/10.1111/j.1467-8268.2003.00072.x

3. Ariff, M., Chung, T-F. and Shamsher, M. (2012). Money supply, interest rate, liquidity and shar prices: A test of their rifflinkage. Global Finance Journal, 23, 202 - 220. https://doi.org/10.1016/j.gfj.2012.10.005

4. Asaleye, A. J., Popoola, O., Lawal, A. I., Ogundipe, A. \& Ezenwoke, O. (2018). The credit channels of monetary policy transmission: implications on output and employment in Nigeria. Banks and Bank Systems, 13(4), 103-118. https://doi.org/10.21511/bbs.13(4).2018.10

5. Asaleye, A. J., Isoha, L. A., Asamu, F., Inegbedion, H., Arisukwu, O., Popoola, O. (2018). Financial development, manufacturing sector and sustainability: Evidence from Nigeria. Journal of Social Sciences Research, 4(12), 539546. https://doi.org/10.32861/jssr.412.539.546

6. Ayopo, B. A., Isola, L. A. \& Olukayode, S. R. (2016a). Stock market response to economic growth and interest rate volatility: Evidence from Nigeria. International Journal of Economics and Financial Issues 6(1), 354-360. https://www.econjournals.com/index.php/ijefi/article/view/1608/pdf

7. Ayopo, B. A., Isola, L. A. \& Olukayode, S. R. (2016b). Stock market volatility: Does our fundamentals matter? Ikonomicheski Izsledvania 25(3), 33-42. https://www.ceeol.com/search/article-detail?id=356000

8. Ayopo, B. A., Isola, A. L., and Somoye, R. O. C. (2015). Monetary policy dynamics and the stock market movements: empirical evidence from Nigeria. Journal of Applied Economic Sciences, X38(8), 1179-1188.

9. Isola, L. A., Frank, A. and Leke, B. K. (2015). Can Nigeria achieve Millennium Development Goals? Journal of Social Sciences Research 1(6), 72-78. http://arpgweb.com/?ic=journal\&journal=7\&info=aims

10. Beck, T., \& Levine, R. (2004). Stock markets, banks, and growth: Panel evidence, Journal of Banking and Finance 28, 423-442. https://doi.org/10.1016/S0378-4266(02)00408-9

11. Chelimo, J. K., \& Kiprop, S. K. (2017). Effect of Dividend Policy on Share Price Performance : A Case of Listed Insurance Companies at the Nairobi Securities Exchange, Kenya, International Journal of Accounting, Finance and Risk Management 2(3), 98-106.

12. 12. Ehikioya, B. I. (2015). An Empirical Investigation of the Impact of Dividend Policy on the Performance of Firms in Developing Economies : Evidence from Listed Firms in Nigeria, International Journal of Finance and Accounting 4(5), 245-252.

13. Fama, E. F. (1970). Efficient Capital Markets: A Review of Theory and Empirical Work. The Journal of Finance, 25(2), 383. https://doi.org/10.2307/2325486

14. Fashina, O. A., Asaleye, A. J. Ogunjobi, J. O. \& Lawal, A. I. (2018) Foreign aid, human capital and economic growth nexus: Evidence from Nigeria. Journal of International Studies, 11(2), 104-117. https://doi.org/10.14254/2071-8330.2018/11-2/8

15. Fontaine, C., Haarman, A. and Schmid, S. (2006). The Stakeholder Theory, (December). https://pdfs.semanticscholar.org/606a/828294dafd62aeda92a77bd7e5d0a39af56f.pdf? ga=2.106356099.16940460. $1585141767-825472732.1571135113$

16. Geertsema, P. and Lu, H/ (2019). Regulated price and demand in China's IPO market. Journal of Economics and Business, 106, 105846. https://doi.org/10.1016/j.jeconbus.2019.105846

17. Hintermann, B., Peterson, S., and Rickels, W. (2016). Price and market behaviour in Phase II of the EU ETS: A review of literature. Review of Environmental Economics and Policy, 10(1), 108 -128. https://doi.org/10.1093/reep/rev015

18. Hunjra, A. I.., Chani,M. I. Shahzad, M., Farooq, M., Khan, K. (2014). The Impact of Macroeconomic Variables on Stock Prices in Pakistan. International Journal of Economics and Empirical Research. 2(1), 13-21.

19. Idawati, W. \& Wahyudi, A. (2015). Effect of earning per share (EPS) and return on assets (ROA) against share price on coal mining company listed in Indonesia stock exchange. Journal of Resources Development and Management: An International Peer-reviewed Journal, 7, 79-91.

20. Ilmiyono, A. F. (2019). The effect of ROE, ROA \& EPS towards stock prices in companies sub-sektor construction and building listed in exchange Indonesia effect (IDX). International Journal of Latest Engineering and Management Research 4(8), 24-35 http://www.ijlemr.com/v4-i8.html

21. Kassouri, Y. And Altintas, H. (2020). Threshold cointegration, nonlinearity and frequency domain causality relationship between stock prices and Turkish Lira. Research in International Business and Finance, 52, 101097 https://doi.org/10.1016/j.ribaf.2019.101097

22. Lawal, A. I., Asaleye, A.J, Ise Olorun kami, J., Popoola, O. R. (2018). Economic Growth, Agricultural Output and Tourism Development in Nigeria: An Application of the ARDL Bound Testing Approach. Journal of 
Environmental Management and Tourism, IX, Summer (28), 786-794. https://doi.org/10.14505//jemt.v9.4(28).12

23. Lawal A. I., Ozturk, I., Olanipekun, I. O., Asaleye, A. J. (2020a) Examining the linkages between electricity consumption and economic growth in African economies, Energy. https://doi.org/10.1016/j.energy.2020.118363

24. Lawal, A. I., Oseni, E., Babajide, A. A., Lawal-Adedoyin, B. \& Bonetipin, F. (2020b). The impact of International Financial Reporting Standard (IFRS) adoption on key financial ratios in Nigeria. Humanities \& Social Sciences Reviews eISSN: 2395-6518, Vol 8, No 4, 2020, pp 289-300. https://doi.org/10.18510/hssr.2020.8430

25. Babajide, A., Lawal, A., Asaleye, A., Okafor, T. \& Osuma, G., (2020). Financial stability and entrepreneurship development in sub-Sahara Africa: Implications for sustainable development goals, Cogent Social Sciences, 6: 1798330.

26. Lawal, A. I., Nwanji, T. I., Adama, I.J \& Otekunrin, A. O. (2017a). Examining the nigerian stock market efficiency: Empirical evidence from wavelet unit root test approach. Journal of Applied Economic Sciences, 12(6), 1680-1689.

27. Lawal, A. I., Somoye, R. O. \& Babajide, A. A. (2017b). Are African stock market efficient? Evidence from wavelet unit root test for random walk. Economics Bulletin, 37(4), 2665-2679 http://www.accessecon.com/ Pubs/EB/2017/Volume37/EB-17-V37-I4-P239.pdf

28. Lawal, A. I.,Olayanju, A., Salisu, A. A., Asaleye, A. J., Dahunsi, O., Dada, O., Omoju, O. E., and Popoola, O. R. (2019a). Examining Rational Bubbles in Oil Prices: Evidence from Frequency Domain Estimates. International Journal of Energy Economics and Policy, 9(2), 166-173. https://doi.org/10.32479/ijeep.7463

29. Mogonta, K. \& Pandowo, M. (2016). Analyzing the effects of return on assets, return on equity and earnongs per share on market share price: A study of LQ-45 mining companies listed on Indonesia stock exchange. Journal of Economic, Business and Accounting Research 4(2), 703-713.

30. Ndede, F. W. S., \& Jagongo, A. O. (2014). Dividend Payout by Agricultural Firms in Kenya [ An Empirical Analysis of Firms Listed on the Nairobi Security Exchange], 5(11), 63-74. https://irlibrary.ku.ac.ke/handle/123456789/12610

31. Pandey, M. K. (2019). The effect of internal and external factors on the stock price of pharmaceutical companies in emerging and emerged markets. European Journal of Business and Management, 11(36), 162 - 199. https://www.iiste.org/Journals/index.php/EJBM/article/view/50831/52524

32. Hunjra, A. I., Ijaz, M. S, Chani, M. I., Hassan, S. and Mustafa, U. (2014). Impact of Dividend Policy, Earning per Share, Return on Equity, Profit after Tax on Stock Prices. International Journal of Economics and Empirical Research, 2(3), 109-115.

33. Shi, W., Wang, G., Zhao, X., Feng, X. and Wu, J. (2018) Price determination in the electrolytic aluminum industry: the role of electricity prices. Resource Policy 59, 274-281 https://doi.org/10.1016/j.resourpol.2018.07.014

34. Saragih, J. L. (2018). The effect of return on assets (RoA), return on equity (RoE), and debt to equity ratio (DER) on stock returns in wholesale and retail trade companies listed in Indonesia stock exchange. International Journal of Science and Research Methodology, 8(3) 348-367.

35. Sharif, T., Purohit, H. \& Pillai, R. (2015). Analysis of factors affecting share prices: The case of Bahrain stock exchange. International Journal of Economics \& Finance 7(3), 207-216. https://doi.org/10.5539/ijef.v7n3p207

36. Su, F. and Zhang, J. (2018). Global price discovery in Australian dollar market and its determinants. Pacific-Basin Finance Journal 48, 35 - 55. https://doi.org/10.1016/j.pacfin.2018.01.002

37. Utami, M.R \& Darmawan, A. (2019). Effect of DER, ROA, ROE, EPS and MVA on stock prices in Sharia Indonesia stock index. Journal of Applied Accounting and Taxation 4(1), 15-22.

38. Zainudin, R., Mahdzan,S. N. \& Yet, C. H. (2018). Dividend policy and stock.

39. price volatility of industrial products firms in Malaysia. International Journal of Emerging Markets, 3(1), pp.203217. https://doi.org/10.1108/IJoEM-09-2016-0250

40. Zhang, Y-J. And Sun, Y-F (2016). The dynamic volatility spill over between European carbon trading market and fossil energy market. Journal of Cleaner Production 112, 2654 - 2663. https://doi.org/10.1016/j.jclepro.2015.09.118 